\title{
Angiogenic activity of bovine corpora lutea at several stages of luteal development
}

\author{
D. A. Redmer, A. T. Grazul*, J. D. Kirsch and L. P. Reynolds \\ Department of Animal and Range Sciences, North Dakota State University, Fargo, \\ North Dakota 58105, U.S.A.
}

\begin{abstract}
Summary. Samples from corpus haemorrhagicum, mid-cycle corpus luteum (CL) and late-cycle CL were tested for their abilities to stimulate neovascularization of chorioallantoic membranes (CAM) of developing chicks. Responses were graded from 0 to 4 (4 being the greatest response). Luteal tissue implants from each stage of the oestrous cycle stimulated growth of CAM blood vessels, and vascular responses increased with age of CL. Implants from late-cycle CL were typically graded 3 or 4 . Luteal tissues from several stages of development were also incubated for $6 \mathrm{~h}$ in serum-free medium containing no hormone, LH, PGF- $2 \alpha$ or both hormones. Media conditioned by luteal tissues were assayed for progesterone and tested for their ability to stimulate mitogenesis and migration of bovine aortic endothelial cells in vitro. All media conditioned by luteal tissues stimulated mitogenesis and migration of endothelial cells, but media from late-cycle $\mathrm{CL}$ exhibited the greatest activity. Luteinizing hormone significantly increased in-vitro secretion of a factor(s) that stimulated migration of endothelial cells. PGF-2 $\alpha$ alone had no effect on production of endothelial cell mitogen or migrationstimulating factor(s) from luteal incubations; however, the ability of LH to enhance secretion of the migration-stimulating factor(s) was blocked by PGF-2 $\alpha$. This study demonstrates that angiogenic activity of bovine luteal tissues increases with age of the $\mathrm{CL}$ and in-vitro secretion of angiogenic factor is responsive to hormones known to regulate luteal function.
\end{abstract}

Keywords: angiogenesis; corpus luteum; cow; oestrous cycle

\section{Introduction}

Regulation of blood vessel growth may be especially important in reproductive tissues (ovary, placenta) which represent normal tissues that exhibit dynamic, periodic growth and regression of vascular beds with concomitant changes in rates of blood flow (Bassett, 1943; Barcroft \& Barron, 1946; Ford et al., 1982; Garverick \& Smith, 1986; Moor \& Seamark, 1986; Reynolds et al., 1986). The cyclic establishment and survival of structures in the ovary (i.e. follicles, corpora lutea) may be dependent on their ability to recruit a vascular supply. That rapidly growing tissues must recruit a blood supply was recognized by Folkman \& Cotran (1976) and Folkman (1982) who demonstrated that tumour growth progressed only if preceded by recruitment and establishment of a functional vascular supply.

Tissue mass of corpora lutea (CL) changes dramatically during the 21-day oestrous cycle of the cow, with concomitant changes in luteal progesterone production (Erb \& Stormshak, 1961; Bowerman \& Melampy, 1962; Erb et al., 1971; Britt et al., 1981; Hansel \& Convey, 1983). Blood

*Visiting scientist from: Animal Physiology Department, University of Agriculture and Technology, 10-718 Olsztyn, Poland. 
flow to the CL also changes rapidly during luteal development, and the mature CL receives one of the greatest rates of blood flow of any organ, typically reaching $10-15 \mathrm{ml} / \mathrm{min}$ per gram of tissue during the mid-luteal phase (Bruce \& Moor, 1976; Ford \& Chenault, 1981; Ford et al., 1982). Early investigators, impressed by the extensive development of luteal vascular beds, recognized that capillary growth (angiogenesis) may be a primary factor in development and function of CL (Clark, 1900; Andersen, 1926; Bassett, 1943). Little is known, however, about regulation of luteal angiogenesis.

Several studies present compelling evidence that luteal tissue is highly angiogenic. Tissues from corpora lutea of several species have been shown to stimulate growth of blood vessels in various invivo bioassays (Jakob et al., 1977; Gospodarowicz \& Thakral, 1978; Koos \& LeMaire, 1983a,b). Likewise, extracts of luteal tissues stimulate mitogenesis of endothelial cells (Gospodarowicz \& Thakral, 1978; Heder et al., 1979). Primate CL secrete a factor(s) that stimulates migration of endothelial cells (Redmer et al., 1985). The aim of the present investigation was to study angiogenic activity of bovine luteal tissue from different stages of the oestrous cycle. Experiments were also designed to investigate in-vitro production and/or release of angiogenic factors from luteal tissues and to determine the effects of luteotrophic and luteolytic hormones on production of these factors. Preliminary results have been reported in abstract form (Grazul et al., 1986).

\section{Materials and Methods}

Preparation of luteal tissue. Ovaries were collected from non-pregnant cows at slaughter and classified as corpora haemorrhagica (about Days 1-4 of the oestrous cycle), mid-cycle CL (about Days 5-17) or regressing late-cycle CL (about Days 18-20). Stage of luteal development was assessed as described by Ireland et al. (1980). Immediately after collection, ovaries were placed into sterile phosphate-buffered saline (PBS; $0.01 \mathrm{M}$-phosphate, $0 \cdot 14 \mathrm{M}-\mathrm{NaCl}, \mathrm{pH} 7 \cdot 3$ ) containing antibiotics $(100 \mathrm{u}$ penicillin $/ \mathrm{ml} ; 100 \mu \mathrm{g}$ streptomycin $/ \mathrm{ml})$ and transported to the laboratory. Luteal tissue was dissected from the ovary, rinsed in sterile PBS, then minced into small pieces in PBS containing antibiotics. Minced luteal tissue was then used in the chick chorioallantoic membrane bioassay or prepared for incubation. Bovine fetal semitendinosus muscle, used as a control tissue for the chick chorioallantoic membrane bioassay, was prepared similarly to luteal tissue.

Chick chorioallantoic membrane bioassay. The bioassay was used for in-vivo measurement of angiogenic activity of bovine luteal tissues. The bioassay used in this study was modified (Reynolds et al., 1987) from the false air sac technique described by Phillips \& Kumar (1979). Samples from each tissue were placed onto each of 5 egg membranes (one tissue sample/egg) within $3 \mathrm{~h}$ of slaughter. Vascularization responses were evaluated by 4 independent observers without knowledge of which treatment was assigned to each egg, and graded from 0 to 4 as described by Vu et al. (1985), with 4 being an exceptional vascularization response.

Incubation of luteal tissue. Luteal tissue was cultured in serum-free media [DMEM and HAM's F10 (1:1 v/v), Gibco, Grand Island, NY] supplemented with BSA $(4 \mathrm{mg} / \mathrm{ml}$; Fraction V, Sigma, St Louis, MO), bovine insulin (300 mi.u./ml: Gibco), transferrin ( $5 \mu \mathrm{g} / \mathrm{ml}$ : Sigma), hydrocortisone (40 ng/ml: Sigma), penicillin ( $50 \mathrm{U} / \mathrm{ml}: \mathrm{Gibco})$ and streptomycin $(50 \mu \mathrm{g} / \mathrm{ml}$ : Gibco). Hormone treatments consisted of media containing a final concentration of (1) no hormone, (2) bovine luteinizing hormone (LH, $1 \mu \mathrm{g}$ USDA-b5/ml), (3) prostaglandin (PG) F-2 $\alpha$ (1 $\mu \mathrm{g} / \mathrm{ml}: \mathrm{Upjohn}$, Kalamazoo, MI) or (4) LH and PGF-2 $\alpha$. Minced samples of tissue (200 mg) from each corpus haemorrhagicum or CL were incubated in $3 \mathrm{ml}$ medium in polystyrene culture tubes. Tubes were placed into a $37^{\circ} \mathrm{C}$ shaking water bath at 100 cycles/min and preincubated for $30 \mathrm{~min}$ before addition of hormones. After preincubation, hormones were added and tissues were incubated for an additional $6 \mathrm{~h}$. Luteal conditioned media were then centrifuged at $400 \mathrm{~g}$ for $5 \mathrm{~min}$ and stored at $-20^{\circ} \mathrm{C}$ until assayed for progesterone and angiotrophic activity. For control, tubes were incubated without tissue but with the above serum-free media (with and without hormones).

Endothelial cell mitogenesis and migration bioassays. The ability of media conditioned by luteal tissues to stimulate mitogenesis of endothelial cells was used as an estimate of angiogenic activity (Gospodarowicz \& Thakral, 1978; Shepro \& D'Amore, 1984; Koos, 1986) with procedures described by Redmer et al. (1987) and Reynolds et al. (1987). Samples of conditioned media were assayed at a final concentration of $20 \%$.

To test the ability of luteal conditioned media to stimulate migration of endothelial cells in vitro, chemotaxis assays were conducted as described by Redmer et al. (1985) and Redmer et al. (1987) with the following modifications. Bottoms of wells of 48-well microchemotaxis chambers (Neuroprobe, Bethesda, MD) were filled with control or luteal conditioned medium (30\%), and an $8 \mu \mathrm{m}$-pore polycarbonate membrane (Nuclepore, Pleasanton, CA) was placed on top. With the top plate affixed over the membrane, $8.5 \times 10^{4}$ trypsinized endothelial cells suspended in control medium were placed in the tops of wells. After 5 -h incubation at $37^{\circ} \mathrm{C}\left(5 \% \mathrm{CO}_{2}, 95 \%\right.$ air $)$, the cells that had not migrated were removed and the membrane was fixed, stained (Diff-Quik, American Scientific Products, McGraw 
Park, IL) and mounted on a glass slide. The number of migrated cells/well was determined by counting under a microscope. Each sample was assayed in triplicate wells.

Progesterone radioimmunoassay. Progesterone was measured in $10 \mu \mathrm{l}$ or less of unextracted media by radioimmunoassay (Redmer \& Day, 1981). Antiserum (Arnell Products Co., New York, NY) was produced in sheep against deoxycorticosterone-21-BSA conjugate (100\% cross-reactivity with progesterone). Samples of luteal conditioned media added at $2 \cdot 5,5,10,25,50$ and $100 \mu 1$ were parallel to the standard curve. A curve established from serial dilution of unconditioned media containing a known amount of added progesterone was also parallel to the standard curve with a regression equation of $y=-5.8+0.9 x(y=$ pg progesterone measured, $x=$ pg progesterone added; $r=0.99$ ). Assay sensitivity was $12 \mathrm{pg} / \mathrm{tube}$, and intra- and inter-assay coefficients of variation were 4.8 and $12 \cdot 6 \%$, respectively.

Statistical procedures. Data from the chorioallantoic membrane assay were analysed by using least-squares analysis of variance for a completely randomized design. Data from the progesterone, mitogenesis and migration assays were analysed using least-squares analysis of variance for a $3 \times 2 \times 2$ factorial design with stage of cycle, concentration of $\mathrm{LH}$, and concentration of PGF- $2 \alpha$ as the main effects. All interactions were included in the model. When the F-test was significant $(P<0.05)$ differences between specific means were evaluated by using the Bonferroni $t$ test (Kirk, 1968).

\section{Results}

Luteal tissues from each stage of the oestrous cycle (16 cows/stage) stimulated formation of 'spokewheel' vascular patterns on the chorioallantoic membrane. Fetal muscle $(n=5)$ caused minimal vascular response (graded $0.5 \pm 0 \cdot 2$; see Fig. 1). Angiogenic activity of luteal tissue increased $(P<0.05)$ as the luteal phase progressed (graded $1.9 \pm 0.2$ and $2.4 \pm 0.2$ for corpora haemorrhagica and mid-cycle $C L$ ), with late-cycle luteal tissues exhibiting the greatest vascular 'spokewheel' responses on the chorioallantoic membrane (graded $3 \cdot 0 \pm 0 \cdot 1$; see Fig. 1).

Media conditioned by luteal tissues of each stage stimulated $(P<0.01)$ proliferation of endothelial cells. Overall mean number of cells/well in control medium after $72 \mathrm{~h}$ incubation was $1.02 \pm 0.01 \times 10^{5}$ and data are expressed as percentage of control medium response. Activity from conditioned media of late-cycle CL $(197 \pm 15 \% ; n=10)$ was greater $(P<0.01)$ than activity found in media conditioned by mid-cycle CL $(160 \pm 8 \% ; n=10)$ or corpora haemorrhagica $(136 \pm 14 \% ; n=9)$. LH and PGF-2 $\alpha$ (alone or in combination) had no significant effect on endothelial cell mitogenesis or on luteal secretion of mitogenic activity.

Conditioned media from all luteal tissues stimulated $(P<0.01)$ migration of endothelial cells (Fig. 2). Migration-stimulating activity of conditioned media was greater $(P<0.05)$ in media from late-cycle $C L$ than in conditioned media for the other 2 stages of the oestrous cycle. Addition of LH to luteal incubations increased $(P<0.01)$ migration-stimulating activity of conditioned media across all stages compared to treatments without LH (Fig. 2). PGF-2 $\alpha$ blocked $(P<0 \cdot 01)$ the LH-induced increase of migration-stimulating activity but had no effect on basal secretion of this activity (Fig. 2). No significant stage of cycle by LH or PGF-2 $\alpha$ interactions were observed. LH and PGF- $2 \alpha$ (alone or in combination) in control media had no effect on endothelial cell migration (mean number of migrated cells/well $=1.7 \pm 0.1 \times 10^{3}$ ).

Luteinizing hormone alone stimulated $(P<0.05)$ in-vitro progesterone production from corpora haemorrhagica and mid-cycle CL (Table 1). PGF- $2 \alpha$ increased $(P<0.05)$ progesterone production by corpora haemorrhagica only. In corpora haemorrhagica and mid-cycle CL, progesterone concentrations in conditioned media containing both $\mathrm{LH}$ and PGF-2 $\alpha$ were similar to concentrations in media without hormones. Conditioned media from late-cycle $\mathrm{CL}$ contained significantly less $(P<0.01)$ progesterone than did media from other luteal tissues.

\section{Discussion}

Proliferation of capillary vessels is thought to consist of at least 3 processes: fragmentation of existing capillary basement membrane, migration of endothelial cells from existing vessels, and 

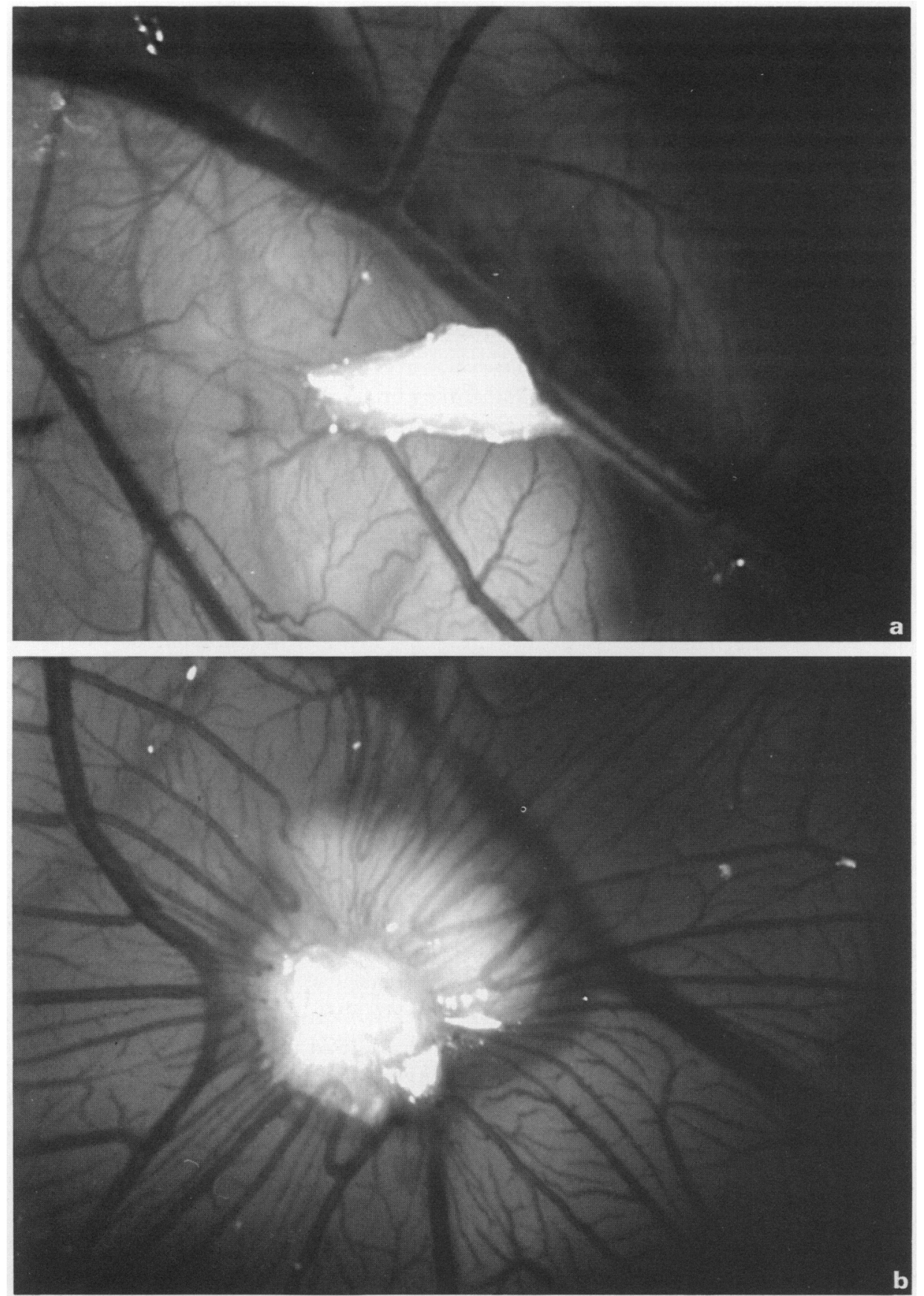

Fig. 1. Vascular responses of chick chorioallantoic membranes to fetal muscle (a) and regressing late-cycle corpus luteum (b). $\times 25$. 


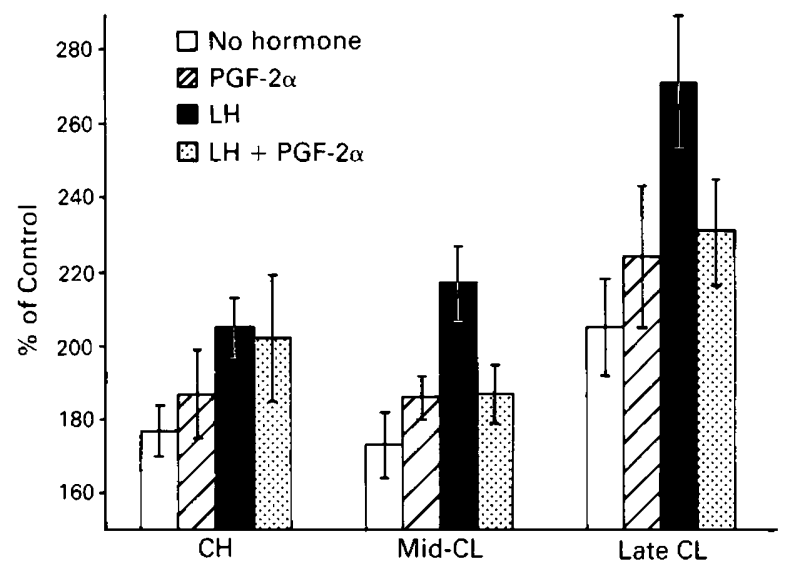

Fig. 2. Effects of conditioned media from incubations of corpora haemorrhagica $(\mathrm{CH} ; n=9)$, mid-cycle corpora lutea (mid-CL; $n=10$ ) or regressing late-cycle CL (late CL; $n=10$ ) on endothelial cell migration. Values are means \pm s.e.m.

Table 1. Progesterone production (ng/mg tissue per $6 \mathrm{~h}$ ) by incubated bovine luteal tissues in response to luteinizing hormone (LH) and prostaglandin F-2 $\alpha$ (PGF)

\begin{tabular}{lccc}
\hline Treatment & $\begin{array}{c}\text { Corpus } \\
\text { haemorrhagicum } \\
(\mathrm{N}=9)\end{array}$ & $\begin{array}{c}\text { Mid-cycle } \\
\text { corpus luteum } \\
(\mathrm{N}=10)\end{array}$ & $\begin{array}{c}\text { Late-cycle } \\
\text { corpus luteum } \\
(\mathrm{N}=10)\end{array}$ \\
\hline No hormone & $97 \cdot 4 \pm 14 \cdot 8$ & $99 \cdot 1 \pm 14 \cdot 0$ & $19 \cdot 8 \pm 14 \cdot 0$ \\
LH & $172 \cdot 0 \pm 14 \cdot 8^{*}$ & $139 \cdot 4 \pm 14 \cdot 0^{*}$ & $35 \cdot 5 \pm 14 \cdot 0$ \\
PGF & $168 \cdot 8 \pm 14 \cdot 8^{*}$ & $107 \cdot 0 \pm 14 \cdot 0$ & $38 \cdot 8 \pm 15 \cdot 7$ \\
LH + PGF & $106 \cdot 8 \pm 15 \cdot 7$ & $106 \cdot 0 \pm 14 \cdot 0$ & $34 \cdot 8 \pm 15 \cdot 7$ \\
\hline
\end{tabular}

Values are mean \pm s.e.m. for the no. of cows indicated.

$* P<0.05$ compared with no hormone.

proliferation of endothelial cells (Shepro \& D'Amore, 1984). The present studies included in-vitro bioassays that evaluated two of these components of angiogenesis (mitogenesis and migration of endothelial cells) as well as an in-vivo bioassay that evaluated true blood vessel formation. All luteal tissue samples stimulated chorioallantoic membrane 'spokewheel' vascular responses. Likewise, all luteal tissues secreted a factor(s) in vitro that stimulated both proliferation and migration of endothelial cells. The overall increase in mitogenic and migration-stimulating activities of luteal conditioned media with stage of luteal development was similar to the vascular responses observed in the chorioallantoic membrane assay. These results indicate that bioassays for endothelial cell mitogenesis and migration provide an accurate and quantitative method for in-vitro evaluation of angiogenic activity.

Because production of progesterone by luteal tissues as well as tissue responses to LH and PGF$2 \alpha$ were similar to those reported previously (Armstrong \& Black, 1966; Milvae \& Hansel, 1983; Pate $\&$ Condon, 1984), the incubation procedure used herein seemed adequate for maintenance of normal luteal functions. Bovine luteal tissues from all stages of the oestrous cycle were angiogenic. As shown by others (Jakob et al., 1977; Gospodarowicz \& Thakral, 1978; Koos \& LeMaire, 1983a,b), fresh luteal tissue was able to stimulate formation of blood vessels in vivo. Although all 
luteal tissue, whether developing or regressing, contained angiogenic activity in the present study, late-cycle $\mathrm{CL}$ exerted the greatest angiogenic response in in-vivo and in-vitro bioassays. Marked 'spokewheel' infiltration of chorioallantoic membrane blood vessels to the site of implantation of tissue samples as well as a complex web of blood vessels around the luteal implant was often observed for late-cycle CL. Koos \& LeMaire (1983a) reported that chorioallantoic membrane vessels often infiltrated and revascularized luteal tissue implants from rats. In the present studies the implanted luteal tissues were not examined histologically; however, when observed by stereomicroscopy $(\times 40)$, erythrocytes in capillary vessels could usually be seen penetrating the surface of implants from late-cycle $\mathrm{CL}$.

In considering luteal vascular development, our initial hypothesis was that early, developing $\mathrm{CL}$ would contain the greatest angiogenic activity to sustain rapid growth, increased blood flow and metabolic activity (Erb \& Stormshak, 1961; Bruce \& Moor, 1976; Ford \& Chenault, 1981; Ford et al., 1982). The present studies, however, demonstrated that, although angiogenic activity was present in corpora haemorrhagica, late-cycle CL were more active in stimulating angiogenesis as estimated by all three bioassays. Since termination of luteal function includes degeneration of luteal tissue and decreased steroidogenesis (Erb \& Stormshak, 1961; Armstrong \& Black, 1966; Milvae \& Hansel, 1983) concomitant with vascular atrophy (Niswender et al., 1976; Koos \& LeMaire, 1983a Doboszynska \& Ziecik, 1986), it seems paradoxical that tissue from late-cycle CL exhibited the greatest angiogenic activity. However, during luteolysis the rapid reduction in luteal weight may be accompanied by restructuring of vascular networks to aid in the resorption of degenerating luteal tissue. Earlier reports (Anderson, 1926; Bassett, 1943; Moss et al., 1954) showed that regressing CL and those from the previous oestrous cycle undergo continuous vascular restructuring. Likewise, the late-cycle CL appears to have a complex vascular organization, and resorption of the vascular bed does not keep pace with the rapid regression of the parenchyma (Bassett, 1943). Endothelial cells of rat corpora lutea exhibit dramatic changes in mitotic index throughout gestation, with the greatest mitotic rates occurring during mid-pregnancy (Meyer \& Bruce, 1979; Tamura \& Greenwald, 1987). Thus development of luteal microvasculature seems to be a dynamic process. Alternatively, in the present study, the observed increases in angiogenic activity of late-cycle CL could result from an initial rebound in luteal tissue function following removal from an inhibitory in-vivo environment.

In the present study, LH stimulated luteal production and/or release of a factor(s) that stimulated migration of endothelial cells and response to $\mathrm{LH}$ was similar across all stages of the oestrous cycle. Luteinizing hormone has been shown to have several other effects on the ovarian vascular system: LH induces luteal hyperaemia and increases blood flow to the CL (Niswender et al., 1976), and causes degranulation of mast cells (Krishna \& Terranova, 1985). It has been suggested, therefore, that $\mathrm{LH}$-induced hyperaemia may be mediated by release of histamine from mast cells. Likewise, glycosaminoglycans such as heparin, another product of mast cells, have been shown to influence the angiogenic process (Folkman et al., 1983; Folkman, 1985) and may be involved in luteal angiogenesis. This report demonstrates for the first time that, not only does bovine luteal tissue secrete endothelial cell mitogenic and migration-stimulating factor(s) in vitro, but secretion of migration-stimulating factor may be regulated, in part, by LH. A previous report by Redmer et al. (1985) demonstrated that the primate CL also secretes an endothelial cell migration-stimulating factor. Although addition of human chorionic gonadotrophin (hCG) to luteal cell incubations in that study had no significant effect on secretion of angiotrophic activity, luteal-conditioned media from hCG-stimulated luteal cell cultures tended to have greater endothelial cell migrationstimulating activity compared to controls. Furthermore, consistent with a previous report (Redmer et al., 1987), results from the present experiment suggest that the migration-stimulating factor(s) is different from the mitogenic factor(s), since only one is stimulated by LH. These data support the notion that luteal angiogenesis is a very complex process with perhaps many different regulators.

Prostaglandin F-2 $\alpha$ inhibited LH-induced increases in luteal production of endothelial cell migration-stimulating factor(s). Since PGF is luteolytic in the cow (Inskeep, 1973; Hafs et al., 
1974), it may act to block stimulation and/or maintenance of vascular formation by $\mathrm{LH}$, which in turn may be involved in the cessation of luteal function. This phenomenon also supports the explanation that the greater activity found in media conditioned by late-cycle CL resulted from a rebound in angiogenic factor production following removal of the regressing luteal tissue from an otherwise suppressive (luteolytic) in-vivo environment.

In summary, the results from these studies show that bovine luteal tissues from several stages of the oestrous cycle stimulate in-vivo and in-vitro angiogenic responses and activity increases during the cycle. Our data also suggest that a luteoangiotrophic action of LH may be directed at endothelial cell migration, and that migration may be blocked by the luteolytic hormone PGF- $2 \alpha$. These findings emphasize the critical role hormones may play in luteal vascular dynamics. Their effects on various components of the angiogenic process may, therefore, be important determinants of overall luteal function.

We thank the National Hormone and Pituitary Program and the USDA for bovine LH; the Upjohn Corp. for PGF-2 $\alpha$; M. Swantek for technical assistance; and J. Berg for typing the manuscript.

Published with approval of the Director of the North Dakota Agricultural Experiment Station as Journal Article No. 1596. Supported by Hatch Projects ND1780 and ND1782 and a grant from the National Science Foundation (RII8610675).

\section{References}

Anderson, D.H. (1926) Lymphatics and blood vessels of the ovary of the sow. Carnegie Instn Contrib. Embryol. 17, 107-127.

Armstrong, D.T. \& Black, D.L. (1966) Influence of luteinizing hormone on corpus luteum metabolism and progesterone biosynthesis throughout the bovine estrous cycle. Endocrinology 78, 937-944.

Barcroft, J. \& Barron, D.H. (1946) Observations upon the form and relations of the maternal and fetal vessels in the placenta of the sheep. Anat. Rec. 94, 569-595.

Bassett, D.L. (1943) The changes in the vascular pattern of the ovary of the albino rat during the estrous cycle. Am. J. Anat. 73, 251-291.

Bowerman, A.M. \& Melampy, R.M. (1962) Progesterone and $\Delta^{4}$-pregnen-20 $\beta$-ol-3-one in bovine reproductive organs and body fluids. Proc. Soc. exp. Biol. Med. 109, 45-48.

Britt, J.H., Cox, N.M. \& Stevenson, J.S. (1981) Advances in reproduction in dairy cattle. J. Dairy Sci. 64, 1378-1402.

Bruce, N.W. \& Moor, R.M. (1976) Capillary blood flow to ovarian follicles, stroma and corpora lutea of anaesthetized sheep. J. Reprod. Fert. 46, 299-304.

Clark, J.G. (1900) The origin, development and degeneration of the blood vessels of the human ovary. Johns Hopkins Hosp. Rep. 9, 593-676.

Doboszynska, T. \& Ziecik, A. (1986) Histomorphological comparison of the ovaries in early-pregnant and oestradiol-treated pigs. Anim. Reprod. Sci. 10, 225-235.

Erb, R.E. \& Stormshak, F. (1961) Progestins in corpora lutea, ovaries, and adrenals after estrus and breeding of normal and abnormal cows. J. Diary Sci. 44, 888-896.

Erb, R.E., Surve, A.H., Callahan, C.J. \& Randel, R.D. (1971) Reproductive steroids in the bovine. VII. Changes postpartum. J. Anim. Sci. 33, 1060-1071.
Folkman, J. (1982) Angiogenesis: initiation and control. Ann. N.Y. Acad. Sci. 401, 212-227.

Folkman, J. (1985) Regulation of angiogenesis: a new function of heparin. Biochem. Pharm. 34, 905-909.

Folkman, J. \& Cotran, R. (1976) Relation of vascular proliferation to tumor growth. Int. Rev. exp. Path. 16, 207-248.

Folkman, J., Langer, L., Linhardt, R.J., Haudenschild, C. \& Taylor, S. (1983) Angiogenesis inhibition and tumor regression caused by heparin or a heparin fragment in the presence of cortisone. Science, N.Y. 221, 719-725.

Ford, S.P., Reynolds, L.P. \& Magness, R.R. (1982) Blood flow to the uterine and ovarian vascular beds of gilts during the estrous cycle or early pregnancy. Biol. Reprod. 27, 878-885.

Ford, S.P. \& Chenault, J.R. (1981) Blood flow to the corpus luteum-bearing ovary and ipsilateral uterine horn of cows during the oestrous cycle and early pregnancy. J. Reprod. Fert. 62, 555-562.

Garverick, H.A. \& Smith, M.F. (1986) Mechanisms associated with subnormal luteal function. J. Anim. Sci. 62 (Suppl. 2), 92-105.

Gospodarowicz, D. \& Thakral, K.K. (1978) Production of a corpus luteum angiogenic factor responsible for proliferation of capillaries and neovascularization of the corpus luteum. Proc. natn. Acad. Sci. U.S.A. 75, 847-851.

Grazul, A., Kirsch, J.D. \& Redmer, D.A. (1986) Angiogenic activity at several stages of luteal development in the cow. J. Anim. Sci. 63 (Suppl. 1), 335, Abstr.

Hafs, H.D., Louis, T.M., Noden, P.A. \& Oxender, W.D. (1974) Control of the estrous cycle with prostaglandin $F_{2} \alpha$ in cattle and horses. J. Anim. Sci. 38 (Suppl. 1), $10-21$. 
Hansel, W. \& Convey, E.M. (1983) Physiology of the estrous cycle. J. Anim. Sci. 57 (Suppl. 2), 404-424.

Heder, G., Jakob, W., Halle, W., Mauersberger, B., Kambach, G., Jentzsch, K.D. \& Oehme, P. (1979) Influence of porcine corpus luteum extract on DNA synthesis and proliferation of cultivated fibroblasts and endothelial cells. Exp. Path. 17, 493-497.

Inskeep, E.K. (1973) Potential uses of prostaglandins in control of reproductive cycles of domestic animals. $J$. Anim. Sci. 36, 1149-1157.

Ireland, J.J., Murphee, R.L. \& Coulson, P.B. (1980) Accuracy of predicting stages of bovine estrous cycle by gross appearance of the corpus luteum. J. Dairy Sci. 63, 155-160.

Jakob, W., Jentzsch, K.D., Mauersberger, B. \& Oehme, P. (1977) Demonstration of angiogenesis-activity in the corpus luteum of cattle. Exp. Path. 13, 231-236.

Kirk, R.E. (1968) Experimental Design: Procedures for the Behavioral Sciences, Wadsworth, Belmont, CA.

Koos, R.D. (1986) Stimulation of endothelial cell proliferation by rat granulosa cell-conditioned medium. Endocrinology 119, 481-489.

Koos, R.D. \& LeMaire, W.J. (1983a) Factors that may regulate the growth and regression of blood vessels in the ovary. Semin. Reprod. Endocrinol. 1, 295-307.

Koos, R.D. \& LeMaire, W.J. (1983b) Evidence for an angiogenic factor from rat follicles. In Factors Regulating Ovarian Function, pp. 191-195. Eds G. S. Greenwald \& P. F. Terranova. Raven Press, New York.

Krishna, A. \& Terranova, P.F. (1985) Alterations in mast cell degranulation and ovarian histamine in the proestrous hamster. Biol. Reprod. 32, 1211-1217.

Meyer, G.T. \& Bruce, N.W. (1979) The cellular pattern of corpus luteal growth during pregnancy in the rat. Anat. Rec. 193, 823-830.

Milvae, R.A. \& Hansel, W. (1983) Prostacyclin, prostaglandin $\mathrm{F}_{2} \alpha$ and progesterone production by bovine luteal cells during the estrous cycle. Biol. Reprod. 29, $1063-1068$.

Moor, R.M. \& Seamark, R.F. (1986) Cell signaling, permeability and microvasculatory changes during antral follicle development in mammals. J. Dairy $S c i$. 69, 927-943.

Moss, S., Wrenn, T.R. \& Sykes, J.F. (1954) Some histological and histochemical observations of the bovine ovary during the estrous cycle. Anat. Rec. 120 , 409-433.

Niswender, G.D., Reimers, T.J., Diekman, M.A. \& Nett, T.M. (1976) Blood flow: a mediator of ovarian function. Biol. Reprod. 14, 64-81.

Pate, J.L. \& Condon, W.A. (1984) Effects of prostaglandin $\mathrm{F}_{2} \alpha$ on agonist-induced progesterone production in cultured bovine luteal cells. Biol. Reprod. 31, 427-435.

Phillips, P. \& Kumar, S. (1979) Tumour angiogenesis factor (TAF) and its neutralisation by venogeneic antiserum. Int. J. Cancer 23, 82-88.

Redmer, D.A. \& Day, B.N. (1981) Ovarian activity and hormonal patterns in gilts fed allyl trenbolone. $J$. Anim. Sci. 53, 1099-1094.

Redmer, D.A., Rone, J.D. \& Goodman, A.L. (1985) Evidence for a non-steroidal angiotropic factor from the primate corpus luteum: stimulation of endothelial cell migration in vitro. Proc. Soc. exp. Biol. Med. 179, 136-140.

Redmer, D.A., Kirsch, J.D. \& Grazul, A.T. (1987) Invitro production of angiotropic factor by bovine corpus luteum: partial characterization of activities that are chemotactic and mitogenic for endothelial cells. Adv. Exp. Med. Biol. 219, 683-688.

Reynolds, L.P., Ferrell, C.L., Robertson, D.A. \& Ford, S.P. (1986) Metabolism of the gravid uterus, foetus and utero-placenta at several stages of gestation in cows. J. agric. Sci., Camb. 106, 437-444.

Reynolds, L.P., Millaway, D.S., Kirsch, J.D., Infeld, J.E. \& Redmer, D.A. (1987) Angiogenic activity of placental tissues of cows. J. Reprod. Fert. 81, 233-240.

Shepro, D. \& D'Amore, P.A. (1984) Physiology and biochemistry of the vascular wall endothelium. In Handbook of Physiology, Section 2, The Cardiovascular System, Vol. IV. Microcirculation, Part I, pp. 103-164. Eds E. M. Renkin \& C. C. Michel. American Physiological Society, Washington, D.C.

Tamura, H. \& Greenwald, G.S. (1987) Angiogenesis and its hormonal control in the corpus luteum of the pregnant rat. Biol. Reprod. 36, 1149-1154.

Vu, M.T., Smith, C.F., Burger, P.C. \& Klintworth, G.K. (1985) Methods in laboratory investigation: An evaluation of methods to quantitate the chick chorioallantoic membrane assay in angiogenesis. $L a b$ Invest. 53, 499-508.

Received 19 June 1987 